\title{
Enhancement of groundwater potential by aquifer artificial recharge techniques: an adaptation to climate change
}

\section{B. EL MANSOURI \& L. EL MEZOUARY}

University Ibn Tofail, Faculty of Sciences, Lab. Geosciences of Natural resources, Hydroinformatic Section, BP 133, 14000, Kénitra, Morocco

b elmansouri@yahoo.fr

\section{INTRODUCTION}

Climate change is already a reality affecting, in particular, several countries of the Mediterranean Sea. The impact of this change on water resources is very important; indeed, climate observations highlight periods of droughts and floods, which we call extreme events. To reduce the effect of these two phenomena on the quantitative degradation or lack of water resources due to changes in rainfall, artificial recharge techniques are a solution to adapting to this situation. The excess water generated by floods on watersheds could be retained in basins to be injected into the aquifer reservoir after the identification of suitable sites for groundwater recharge.

The development of numerical tools can enhance the studies and the conceptions of aquifer artificial recharge operations. Indeed, these tools, particularly numerical models, by way of numerical simulations, can give the behaviour of response of the aquifer (water table) to the induced infiltration. In addition, the use of these numerical tools is an opportunity for synthesis of all data of the aquifer in order to establish a conceptual model first.

\section{AQUIFER ARTIFICIAL RECHARGE TECHNIQUES}

Groundwater artificial recharge is achieved by putting surface water in basins, furrows, ditches, or other facilities where it infiltrates into the soil and moves downward to recharge aquifers (Fig.1). The Artificial recharge is increasingly used for short- or long-term underground storage, where it has several advantages over surface storage, and in water re-uses (Bouwer 1996). Three important aspects in artificial groundwater recharge are quantities, the quality of water sources, and the hydraulic properties of the sink area (Seiler and Gat 2007).

- The quantities are responsible for a continuous recharge supply and need optimal reservoir design;

- The quality of water for use in artificial recharge is critical. In fact, the suspended matter has often a disastrous impact on well clogging, which is difficult to clean up, and can be minimized in infiltration basins by selecting graded sand/gravel packs to keep clogging close to the surface of the infiltration interface and, hence, to be easily removable.

- The best subsurface reservoirs for artificial groundwater recharge are unconsolidated sediments with hydraulic conductivities in the range of $10^{-2} \mathrm{~m} / \mathrm{s}$ to $10^{-5} \mathrm{~m} / \mathrm{s}$ and a high storage coefficient. These bulk hydraulic data also stand for efficient groundwater exploitation.

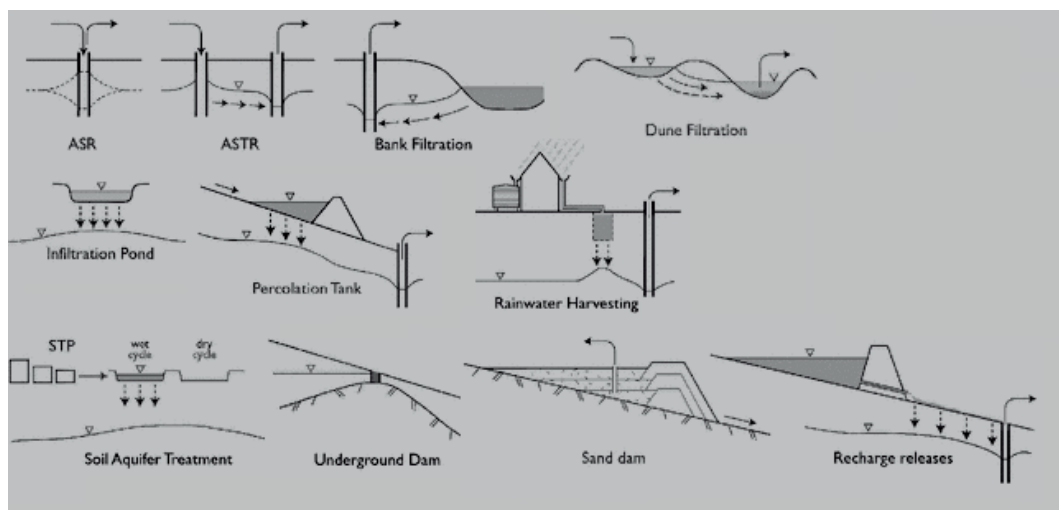

Fig. 1 Schematic of types of aquifer of management recharge; after Dillon (2005). 


\section{AQUIFER ARTIFICIAL RECHARGE: TECHNIQUES MODELLING AND CASE STUDY}

In southern Morocco, the Tafilalet region is known for its arid climate and scarce water resources (Fig. 2(a)). We conducted a study to improve the potential of groundwater resources by exploring the feasibility of artificial groundwater recharge. The first step was the identification of suitable sites for artificial recharge and the availability of surface water resources that would be injected into the aquifer. To carry out this study, we established a GIS database for the physical environment concerning: geology, hydrogeology, watershed hydrology, etc. Data processing using a GIS tool allowed us to identify favorable areas for artificial recharge. These sites are obtained by crossing the raster maps of different hydrogeological parameters (aquifer type, hydraulic conductivity, slope topography, depth to water table, etc.) (Fig. 2(b)).

(a)

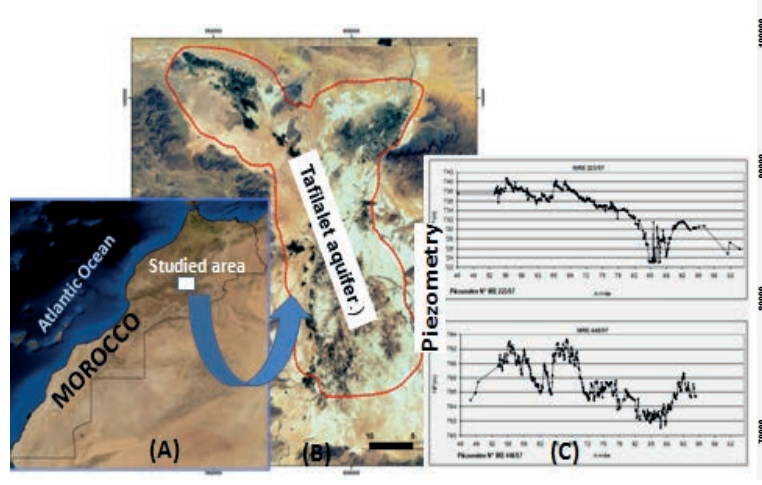

(b)

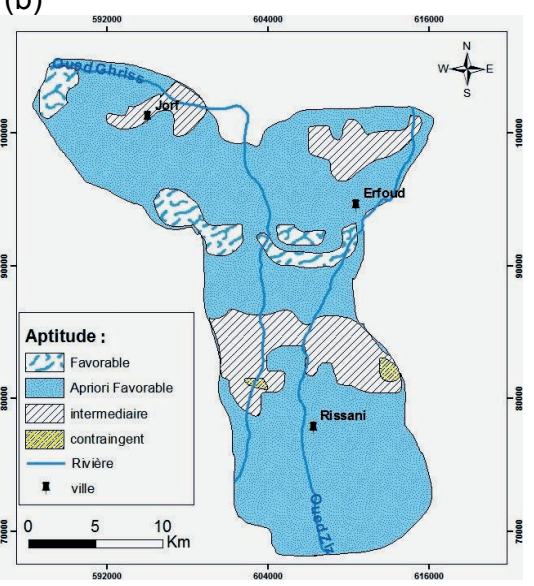

Fig. 2 (a) Tafilalet aquifer location and piezometric evolution; (b) map of suitability for artificial recharge.

The second condition for artificial recharge consists of the quantification of the water surface by calculating the flow generated by the sub-watersheds upstream of the Tafilatet basin. All data were finally integrated into a numerical model for groundwater simulations. After calibration for permanent and transient regime, we performed simulations of aquifer recharge to assess the impact on the piezometric level. An infiltration rate of $1.7 \times 10^{-6} \mathrm{~m} / \mathrm{s}$ was used for the groundwater recharge. This rate could generate a piezometric elevation of 0.5 to $9 \mathrm{~m}$ in the aquifer domain (Fig. 3).

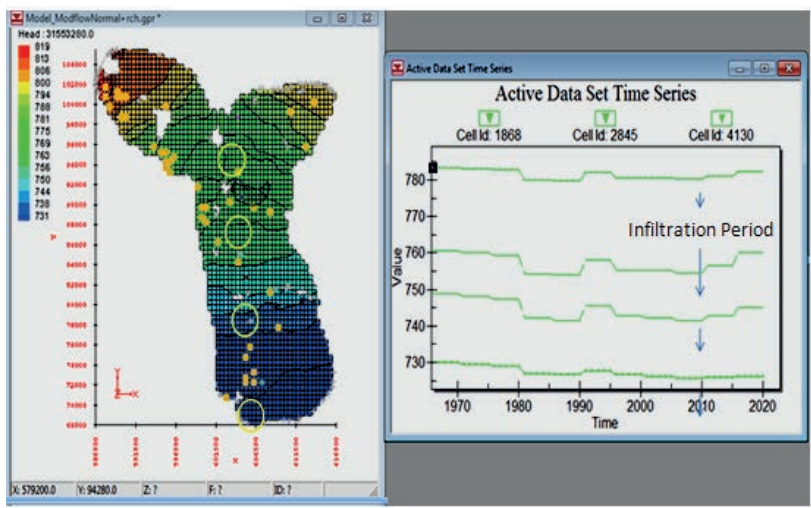

Fig. 3 Numerical simulation of aquifer artificial recharge in Tafilalet aquifer, Morocco.

\section{REFERENCES}

Bouwer, H. (2002) Artificial recharge of groundwater: hydrogeology and engineering. Hydrogeology Journal 10, 121-142 Deller, P. (2005) Future Management of aquifer recharge. Hydrogeology Journal 13(1), 313-316

Seiler, K.P. and Gat, G.R. (2007) Groundwater recharge from run-off, infiltration and percolation. In: V.P. Singh (ed.) Water Science and Technology Library, vol. 55. Texas A\&M University, College Station, USA. Springer. 